Pedagogik Jurnal Pendidikan, Maret 2015, Volume 10 Nomor 1, (51-61)

\title{
PENGGUNAAN MEDIA FACEBOOK UNTUK MENINGKATKAN KETERAMPILAN DAN MOTIVASI MAHASISWA DALAM MENULIS RECOUNT TEXT
}

\author{
Oleh : A’am Rifaldi Khunaifi *
}

\begin{abstract}
Abstrak
Penelitian ini ditujukan untuk mengetahui penggunaan Facebook sebagai media belajar recount text untuk meningkatkan kemampuan menulis dan meningkatkan motivasi siswa semester I STAIN Palangkaraya pada tahun akademik 2013/2014. Penelitian ini bertujuan untuk mengetahui cara meningkatkan kemampuan menulis siswa di media Facebook 1 dan meningkatkan motivasi mereka dalam menulis teks recount. Untuk mencapai tujuan, penelitian tindakan yang dirancang dan dilaksanakan melalui pre-test, siklus 1, dan siklus 2.Subjek penelitian ini adalah 32 siswa semester I STAIN Palangkaraya.menggunakan tes tertulis, lembar observasi, dan kuesioner sebagai instrumen pengumpulan data. Ada lima pertemuan dalam penelitian ini. Pertemuan pertama digunakan untuk melakukan pre-test, pertemuan kedua dan ketiga digunakan untuk melakukan siklus 1 dan formatiftest, dan pertemuan keempat dan kelima digunakan untuk melakukan siklus 2 dan post-test. Hasil penelitian menunjukkan peningkatan yang signifikan dari prestasi siswa. Rata-rata Para siswa di pre-test adalah $(67,75)$, dalam tes formatif adalah $(74,5)$, dan post-test adalah $(79,25)$. Kemampuan Para siswa dalam menulis (organisasi, isi, tata bahasa, tanda baca, dan gaya dan ekspresi) di setiap tes membaik juga. Hasil lembar observasi menunjukkan bahwa setelah mempelajari teks menulis recount menggunakan media Facebook, para siswa menjadi lebih perhatian, aktif, tertarik lebih tertarik dan lebih serius dalam menulis. Analisis kuesioner menunjukkan bahwa siswa memberikan respon positif terhadap penggunaan Facebook dalam media pembelajaran mereka. Berdasarkan hasil keseluruhan penelitian, dapat disimpulkan bahwa penggunaan media Facebook terhadap peningkatan keterampilan dan peningkatan motivasi siswa dalam menulis teks recount.
\end{abstract}

\section{Kata Kunci : Facebook, Recount Text}

\section{PENDAHULUAN}

Bahasa Inggris merupakan bahasa Internasional. Di Indonesia, bahasa Inggris diajarkan sebagai bahasa asing (English as a Foreign Languange/EFL) mulai dari Sekolah Dasar sampai Perguruan Tinggi (Huda, 1999, dalam Saukah, 2003). Orangorangmenyadari bahwa pengajaran bahasa Inggris di tingkat ini menjadi sangat penting dan membutuhkan banyak perhatian. Sebagai seorang guru bahasa Inggris, ia dituntut untuk mengeksplorasi teknik yang efektif, metode dan pendekatan.

Bahasa Inggris diajarkan sebagai bahasa asingdi negara kita, Indonesia. Pengajaran Bahasa Inggris di Indonesia memiliki banyak tantangan karena bukan bahasa asli kita dan tidak umum digunakan dalam kehidupan kita sehari-hari. Selain itu, bahasa Inggris terlihat sulit karena kita tidak mengenalinya sejak kita lahir. Hal ini biasanya diajarkan pertama kali adalah di sekolah, yang di SD atau bahkan SMP hingga perguruan Tinggi.

Pada dasarnya, salah satu sasaran pengajaran dan pembelajaran bahasa Inggris di sekolah atau pun di perguruan tinggi adalah untuk membuat siswa mampu berkomunikasi dalam bahasa Inggris baik lisan maupun bahasa secara tertulis. Untuk mencapai hal ini, ada empat keterampilan bahasa harus diajarkan; yaitu mendengarkan, berbicara, membaca, dan menulis. Mendengarkan dan membaca sifat 
atau keterampilan reseptif, sedangkan berbicara dan menulis merupakan keterampilan aktif atau produktif (Harmer, 2001:199, 246). Semua keterampilan memang penting. Namun, salah satuketerampilan bahasa yang mendorong siswa untuk menjadi lebih produktif dan kreatif yaitu keterampilan menulis(writing Skill).

Akhmad Sudrajat membagi kemampuan menjadi dua jenis, yaitu: a) actual ability, dan b) potential ability. Actual ability atau kecakapan nyata merupakan kecakapan yang diperoleh karena belajar yang dapat segera didemonstrasikan atau diuji sekarang.Potential ability atau kecakapan potensial merupakan aspek kecakapan yang masih terkandung dalam diri individu dan diperoleh dari faktor keturunan. Lebih lanjut menurut Robbins dalam menyatakan bahwa kemampuan terdiri dari dua faktor, yaitu a) kemampuan intelektual (intelectual ability), merupakan kemampuan melakukan aktivitas secara mental, b) kemampuan fisik (physical intellectual), merupakan kemampuan melakukan aktivitas berdasarkan stamina, kekuatan, dan karakteristik fisik.

Kemampuan memiliki kaitan erat dengan inteligensi individu. Kemampuan yang besar akan meningkatkan intelegensi dan sebaliknya. Ada beberapa teori yang mengemukakan keterkaitan kemampuan dengan intelegensi.

Menulis(writing) merupakan salah satu kemampuan berbahasa.Dalam pembagian kemampuan berbahasa, menulis selalu diletakkan paling akhir setelah kemampuan menyimak, berbicara, dan membaca.Meskipun selalu ditulis paling akhir, bukan berarti menulis merupakan kemampuan yang tidak penting.
Dalam menulis(writing) semua unsur keterampilan berbahasa harus dikonsentrasikan secara penuh agar mendapat hasil yang benar-benar baik.Henry Guntur Tarigan (1986: 15) menyatakan bahwa menulis dapat diartikan sebagai kegiatan menuangkan ide/gagasan dengan menggunakan bahasa tulis sebagai media penyampai.

Pengertian menulis diungkapkan juga oleh Barli Bram (2002: 7) in principle, to write means to try to produce or reproduce writen message. Barli Bram mengartikan menulis sebagai suatu usaha untuk membuat atau mereka ulang tulisan yang sudah ada.

Menurut Eric Gould, Robert DiYanni, dan William Smith (1989: 18) menyebutkan writing is a creative act, the act of writing is creative because its requires to interpret or make sense of something: a experience, a text, an event. Menulis adalah perilaku kreatif, perilaku menulis kreatif karena membutuhkan pemahaman atau merasakan sesuatu: sebuah pengalaman, tulisan, peristiwa.

M. Atar Semi (2007: 14) dalam bukunya mengungkapkan pengertian menulis adalah suatu proses kreatif memindahkan gagasan ke dalam lambanglambang tulisan. Burhan Nurgiantoro (1988: 273) menyatakan bahwa menulis adalah aktivitas aktif produktif, yaitu aktivitas menghasilkan bahasa.

Writing (menulis) adalah juga media komunikasi. Menurut Byrne (1980: 24) menulis adalah sarana utama pidato rekaman, meskipun harus diakui sebagai media sekunder komunikasi, sehingga dapat membantu kita untuk memiliki sosialisasi yang baik, dapat mengekspresikan ide kita, perasaan dan pendapat kita sehingga kita dapat memiliki interaksi yang baik dengan masyarakat kita. 
Dibandingkan dengan keterampilan lainnya, menulis dianggap salah satu yang paling rumit bagi siswa yang sedang belajar writing untuk menulis karena mereka harus menguasai banyak aspek yang berhubungan dengan mekanik penulisan (ejaan, tanda baca dan huruf besar), pilihan kata, tata bahasa dan kemampuan untuk menghubungkan kalimat untuk menjadi unifield berpikir dalam wacana tertulis. Writing (menulis) adalah tindakan pribadi di mana penulis mengambil ide-ide dan mengubahnya menjadi topik dikehendaki sendiri (Farris, 1993, O'Malley dan Pierce, 1996).Mengingat kompleksitas penulisan, sulit bagi siswa untuk menghasilkan sebuah paragraf terutama jika hal itu dilakukan dalam bahasa asing seperti bahasa Inggris.Meskipun, writing (menulis) adalah sangat penting bagi kita , tapi itulah subjek yang terutama bagi siswa . Alasannya adalah karena menulis adalah campuran dari ide kita, tes kosakata " ( 1975:138 );

Penulis dapat menyimpulkan bahwa writing (menulis) adalah hal yang sangat penting karena dalam menulis kita harus berbagi ide dari otak kita, tidak mudah untuk menerjemahkan konsep di otak kita untuk menjadi bahasa tertulis dan kita juga harus pandai memilih dan untuk menggabungkan kosakata untuk menciptakan sesuatu yang bermakna. Kita juga harus memperhatikan tata bahasa, sehingga sangat wajar jika siswa berpikir dan menulis adalah pelajaran yang sulit karena mereka harus memperhatikan banyak hal (ide, konsep, kosa kata dan tata bahasa).

Sebenarnya, dalam kehidupan seharihari, kebiasaan menulis telah dibangun oleh siswasendiri melalui media sosial seperti Facebook, Twitter, Google+, dllwww.socialbakers.com melaporkan bahwa pada Februari 2013, Indonesia ditempatkan sebagainegara dengan jumlah tertinggi keempat pengguna Facebook di dunia denganjumlah pengguna mencapai 47.165.080. Hal ini menunjukkan bahwa Indonesia, termasukusia sekolah maupun kalangan mahasiswa atau perguruan tinggi, cukup aktif di Facebook. Dalam jaringan sosial, mereka merasa bebasdan menikmati menulis sesuai pikiran mereka, perasaan, dan pendapat dalam cara informal.

Pendidik dapat mengambil manfaat dari siswa "kegiatan menulis di media Facebook dapat meningkatkan keterampilan dalam menulis dengan memotivasi mereka untuk menulis lebih banyakdan lebih tidak hanya dalam situasi informal, namun juga dalam satu formal.Yang menulis untuktujuan akademik.Hal ini dapat dilakukan karena mereka menikmati menulis seperti itu.

\section{Rumusan Masalah}

Perumusan masalah dalam penelitian ini di uraikan sebagai berikut:

1. Bagaimana facebook dapat meningkatkan keterampilan dalam menulis recount text pada Mahasiswa semester I di STAIN Tahun Akademik 2013/2014 Palangka Raya?

2. Bagaimana facebook dapat meningkatkan motivasi dalam menulis recount text pada Mahasiswa semester I di STAIN Tahun Akademik 2013/2014 Palangka Raya?

\section{Media Facebook}

Facebook adalah salah satu situs jaringan sosial populer yang banyak digunakansaat ini.Banyak peneliti percaya bahwa Facebook memiliki potensi yang baik untuk menjadidigunakan dalam kelas menulis sehingga mereka mencoba untuk memeriksanya dengan melakukan penelitian. 
Facebook adalah jejaring sosial yang perkembangannya sangat pesat di kalangan remaja dewasa ini.Facebook menduduki rangking pertama sebagai jejaring sosial yang terlaris diantara jejaring-jejaring sosial lainnya.

Studi lain dilakukan oleh Eren (2012) yang berjudul Sikap Mahasiswa dalam Menggunakan Jaringan Sosial di Bahasa Asing Kelas: A Facebook Contoh".Penelitian ini bertujuan untuk menyelidiki sikap mahasiswa terhadap penggunaan situs jejaring sosial, Facebook khususnya, di kelas bahasa. penelitian ini dilakukan di sebuah universitas di Gaziantep, Turki dengan 48 sarjana siswa yang terdaftar dalam satu tahun wajib kelas persiapan bahasa Inggris. itu Data dikumpulkan melalui 5 point Likertjenis kuesioner dan semiwawancara terstruktur. Ditemukan bahwa mahasiswa memiliki sikap yang sangat positif terhadap penggunaan aktivitas Facebook sebagai suplemen untuk kelas bahasa.

Namun, berdasarkan kelas tradisional belajar bahasa masih tetap tulang punggung untuk pendidikan bahasa.

Menurut beberapa penelitian sebelumnya tentang mengintegrasikan Facebook resmi masuk dalam belajar bahasa, saya berasumsi bahwa Facebook berpotensi menguntungkan dalam menulis recountdi kelas juga.

\section{Keterampilan Menulis}

Writing (menulis) adalah juga media komunikasi. Menurut Byrne (1980: 24) menulis adalah sarana utama pidato rekaman, meskipun harus diakui sebagai media sekunder komunikasi, sehingga dapat membantu kita untuk memiliki sosialisasi yang baik, dapat mengekspresikan ide kita, perasaan dan pendapat kita sehingga kita dapat memiliki interaksi yang baik dengan masyarakat kita.

Dibandingkan dengan keterampilan lainnya, menulis dianggap salah satu yang paling rumit bagi siswa yang sedang belajar writing untuk menulis karena mereka harus menguasai banyak aspek yang berhubungan dengan mekanik penulisan (ejaan, tanda baca dan huruf besar), pilihan kata, tata bahasa dan kemampuan untuk menghubungkan kalimat untuk menjadi unifield berpikir dalam wacana tertulis. Writing (menulis) adalah tindakan pribadi di mana penulis mengambil ide-ide dan mengubahnya menjadi topik dikehendaki sendiri (Farris, 1993, O'Malley dan Pierce, 1996).Mengingat kompleksitas penulisan, sulit bagi siswa untuk menghasilkan sebuah paragraf terutama jika hal itu dilakukan dalam bahasa asing seperti bahasa Inggris.Meskipun, writing (menulis) adalah sangat penting bagi kita , tapi itulah subjek yang terutama bagi siswa . Alasannya adalah karena menulis adalah campuran dari ide kita, tes kosakata " ( 1975:138);

Writing means producing or creating a piece of text. Like speaking, writing requires someone to produce language. Harmer (2001: 249) states, "Language production means that students should use all and any languages at their disposal to achieve a communicative purpose rather than be restricted to specific practice points". Therefore, the form of language produced is different among those two. Speaking produces language in oral form while writing does in written form. That $\square \mathrm{s}$ why those skills belong to productive skill (Harmer, 2001:246; Harmer, 2004:6.

Menurut Harmer (2001:255), "secara tertulis, ada masalah dengan tata bahasa, kosa kata, tulisan tangan, ejaan, tata letak, dan tanda baca ". Ini berarti 
bahwa konten yang baik menulis saja tidak cukup. Seorang penulis juga harus memiliki cukupkomponen bahasa seperti tata bahasa, kosa kata, tanda baca, dan ejaan untukmemfasilitasi dia / dalam mengungkapkan ide-idenya, pengalaman, pikiran, dan perasaan.Penulisan harus terorganisasi dengan baik, juga, agar dapat dengan mudah dibaca dan dipahami oleh pembaca.

\section{Proses Menulis}

Menulis

tidak sesederhana menempatkan sebuah teks di atas kertas, membutuhkan proses yang panjang. Harmer (2004:4) argues that the process of writing consists of 4 steps: (1) planning, (2) drafting, (3) editing (reflecting and revising), and (4) final version. Harmerberpendapatbahwaalat ProsesPenulisanterdiriBahasa Dari4langkah: (1) perencanaan, (2) penyusunan, (3) editing(mencerminkan Danmerevisi), dan (4) Versifinal.

Langkah pertama menulis adalah perencanaan. Sebelum mulai menulis atau mengetik,penulis perlu merencanakan apa yang akan mereka katakan. Hal ini dapat dilakukan dengan membuat detailcatatan, catatan kata-kata itu, atau hanya berencana di dalam kepala.Harmer (2004:4) proposes three main issues writers should think about when planning to write: (1) the purpose of the writing, (2) the audience they are writing for, and (3) the content structure of the piece.

Langkah kedua adalah penyusunan. Dalam langkah ini, penulis menulis apa yang diatelah direncanakan sebelumnya. Tulisan ini disebut draft pertama karena tidak belum selesai. Penulis harus memeriksa teliti dan membuat perubahan dan koreksi sebelummempertimbangkan sebagai versi final dari tulisan.
Memeriksa draft pertama akan mengarahkan penulis untuk mengeditnya. Ini adalah langkah ketigadari proses penulisan. Dalam langkah ini, penulis membuat perubahan dan koreksi karenaambiguitas, kesalahan tata bahasa, perintah tidak terorganisir, dll tulisan.

\section{Recount Text}

Recount Text adalah salah satu dari jenis teks bahasa Inggris yang menceritakan kembali kejadian-kejadian atau pengalaman-pengalaman di masa lampau. Tujuan dari Recount Text adalah untuk memberikan informasi atau untuk menghibur pembaca.Di dalam Recount Text tidak terdapat komplikasi (Complication) seperti halnya di Narrative Text.

Wignell (1994:194), " genre yang menceritakan kembali peristiwa untuk tujuan menginformasikan dan menghibur". Demikian pula, Anderson (1997:48) mendefinisikan"Menceritakan teks sebagai bagian dari teks yang menceritakan kembali peristiwa masa lalu, biasanya dalam urutanyang terjadi pada mereka".

\section{Motivasi}

(Schunk, Pintrich, dan Meece, 2010). Motivasi sangat penting dalam belajarsesuatu.Ini memberi peserta didik kekuatan untuk berhasil dalam pembelajaran mereka.Harmer(2001:51) menyatakan bahwa "motivasi adalah semacam drive internal yang mendorongseseorang untuk melakukan halhal untuk mencapai sesuatu".

Dari definisi di atas, dapat disimpulkan bahwa pengaruh motivasi perilaku dan belajar. Ormrod (2010) ada beberapa efek motivasi siswa dalam belajar dan perilaku sebagai berikut: (1) mengarahkan perilaku ke arah tujuan tertentu, (2) meningkatkan jumlah 
usaha dan energi bahwa peserta didik mengeluarkan dalam kegiatan yang berkaitan langsung dengan kebutuhan dan tujuan mereka, (3) meningkatkaninisiasi dan ketekunan dalam kegiatan, (4) mempengaruhi apa yang peserta didik memperhatikan seberapa efektif mereka mengolahnya, (5) menentukan mana konsekuensimemperkuat dan menghukum, dan (6) meningkatkan kinerja.

\section{Facebook sebagai Media Pembelajaran}

Bagian ini menyajikan studi teoretis yang berkaitan dengan jaringan sosial dan Facebook,Grup Facebook, media, penggunaan Facebook sebagai media dalam pembelajaran menulis, keuntungan menggunakan Facebook sebagai media dalam menulis pembelajaran, dan kerugianmenggunakan Facebook sebagai media dalam pembelajaran menulis.

a. Jaringan Sosial dan Facebook

Jejaring sosial bukanlah istilah baru saat ini. Hampir semua orang tahu apa itumeskipun mereka tidak bisa mendefinisikannya. Berdasarkan pengetahuan saya yang terbatas, saya mendefinisikan social jaringan sebagai sistem sosial berbasis internet yang terdiri dari banyak orang dari berbagaitempat-tempat yang terhubung bersama-sama untuk memungkinkan komunikasi dan interaksidi antara mereka.

Menurut Bartlett-Bragg (2006:3), "Sebuah jaringan sosial adalah berbagaiaplikasi yang menambah interaksi kelompok dan ruang-ruang bersama untuk kolaborasi,pertukaran informasi hubungan sosial, dan agregat dalam berbasis weblingkungan".

\section{Manfaat Penelitian}

Dengan melakukan penelitan, kita dapat memperoleh manfaat yaitu:

1. Untuk menginformasikan kepada Dosen pengajar tentang keuntungan menggunakan media facebook untuk keterammpilan menulis.

2. Untuk memberikan informasi kepada peneliti lain tentang keuntungan menggunakan media facebook dalam menulis recount text.

\section{Metode Penelitian}

Dalam penelitian ini penulis menggunakan data kuantitatif dan kualitatif.Data kuantitatifadalah analisis statistik dari hasil tes, lembar observasi, dan kuesioner. Sementara itu, data kualitatif adalah deskripsi dan diskusipengajaran dan proses pembelajaran dan hasil dari tiga instrumen (tes,lembar observasi, dan kuesioner).Dalam penelitian ini, peneliti berperan sebagai guru, data kolektor, dan data

analyzer. Sebagai guru, peneliti menyediakan bahan, mengajarkan materi kepada siswa, dan menguji mahasiswa "prestasi. Sebagai seorang kolektor data, peneliti mengumpulkan data yang diperoleh dari observasi, tes, dan angket. Akhirnya, sebagai analisa data, peneliti menganalisis data yang dikumpulkan menggunakan tertenturumus.

\section{Instrumen untuk Pengumpulan Data}

Dalam penelitian ini, ada tiga instrumen (tes, lembar observasi, dan kuesioner) digunakan untuk mengumpulkan data.

Data dari tiga sumber: tes, observasi, dan kuesioner dikumpulkan. Pengamatan dalam bentuk checklist berfungsi untuk mengamati perilaku mahasiswa selama proses belajar mengajar. Data pengamatan dikumpulkan selama proses belajar 
mengajar. Kuesioner dibagikan kepada para mahasiswa setelah seluruh perawatan. Itu digunakan untuk mengetahui informasi tentang persepsi mahasiswa terhadap pemanfaatan Facebook dalam mempelajari teks-teks tertulis recount. Tes diberikan tiga kali (pre-test, tes formatif, dan post-test) dengan tujuan mengukur kemampuan menulis pada mahasiswa sebelum dan sesudah penelitian tindakan yang dilakukan.

Penelitian tindakan ini dilakukan dalam dua siklus dengan empat fase dalam setiap siklus. Ada perencanaan, bertindak, observasi dan refleksi dalam setiap siklus. Hal ini dilakukan dalam lima pertemuan melalui tiga langkah:. Pre-test, siklus 1, dan siklus 2 Kegiatan rinci.
Brown (2004: 244-245). The scoring technique measures the organization;content; grammar; punctuation, spelling, and mechanics, and style and quality of expression with the rate of 1-20 for each aspect.

\section{Hasil Penelitian}

Penelitian tindakan ini dilaksanakan di STAIN Palangka Raya, khususnya di semester I, pada tahun akademik 2013/2014. . Ada tiga kegiatan utama dalam penelitian ini.yaitu pre-test, siklus 1 , dan siklus 2. jadwal penelitian dapat dilihat pada tabel berikut:

Table 1 Jadwal Penelitian

\begin{tabular}{|l|l|l|l|l|l|}
\hline \multirow{2}{*}{ Pctivity } & \multirow{2}{*}{ Pre-Test } & \multicolumn{2}{|c|}{ Cycle 1 } & \multicolumn{2}{|c|}{ Cycle 2 } \\
\cline { 3 - 5 } & Treatments & $\begin{array}{r}\text { Formative } \\
\text { Test }\end{array}$ & Treatments & Post-Test \\
\hline Octbr 29 & & & & \\
\hline Nov 4 & & & \\
\hline Nov $6^{\text {th }}, 2014$ & & & & \\
\hline Nov $11^{\text {th }}, 2014$ & & & & \\
\hline Nov 13 & & & & \\
\hline
\end{tabular}

Untuk detail, saya membagi penelitian menjadi 9 urutan: Pertemuan 1, setelah pertemuan 1 dan sebelum pertemuan kedua, pertemuan 2, setelah pertemuan 2 dan sebelum pertemuan ke 3 , pertemuan 3 , setelah pertemuan ke 3 dan sebelum petemuan 4, pertemuan 4, setelah pertemuan 4 dan sebelum pertemuan ke 5, dan pertemuan 5. garis besar penelitian dapat dilihat pada tabel berikut:

\section{Hasil}

Bagian ini menjelaskan secara rinci pengumpulan data selama pre-test, siklus 1, dan siklus 2 bersama-sama dengan analisis pre-test, tes formatif, dan posttest. Selanjutnya, analisis lembar observasi dan angket. 
Pedagogik Jurnal Pendidikan, Maret 2015, Volume 10 Nomor 1, (51-61)

Pre-Test

Sebelum menerapkan penelitian tindakan dan memberikan beberapa treatment kepada siswa, peneliti memberikan pretest untuk menentukan kemampuan dasar siswa dalam teks tertulis recount. Pre-test dilakukan pada pertemuan pertama dari seluruh penelitian,.

Sebelum memberikan pre-test, saya meminta para siswa bertanya beberapa pertanyaan yang berhubungan dengan pengalaman yang tak terlupakan mereka di masa lalu.dan peneliti juga bertanya apakah mereka pernah mencoba untuk memberitahu pengalaman dalam bentuk lisan atau tertulis. Setelah itu, saya meminta mereka beberapa pertanyaan yang berkaitan dengan menceritakan teks untuk membantu mereka mendapatkan kembali materi tentang hal itu.

Saya mengatakan kepada mereka untuk melakukan pre-test untuk menulis teks recount dengan tema "Momen yang tak terlupakan". Instrumen untuk pre-test dapat dilihat pada lampiran .

\section{Hasil Pre Test}

Saya membaca pekerjaan siswa pada pre-test dan skor berdasarkan skala analitik Brown dan Bailey untuk tugastugas komposisi rating. Skala analitik Brown dan Bailey mengukur lima aspek. Aspek pertama adalah organisasi.Ini berkaitan dengan struktur generik teks.Aspek kedua adalah konten yang berkaitan dengan perkembangan logis dari ide-ide dari teks.Komponen ketiga adalah tata bahasa.Komponen sebagainya adalah tanda baca, ejaan, dan mekanik. Komponen terakhir adalah gaya dan kualitas ekspresi yang sebagian besar ditangani dengan kosa kata.

Dalam menghitung skor siswa, peneliti menyimpulkan skor lima aspek. Dari hasil perhitungan, saya menemukan bahwa ada dua siswa yang mendapat nilai terendah dalam pre-test.Itu adalah 60.Sementara yang tertinggi adalah 81, diperoleh hanya satu siswa.

Setelah menghitung skor, saya menghitung rata-rata siswa "skor menggunakan rumus yang diambil dari Tuckman (1978: 250):

$\begin{aligned} \text { The average of students score } & =\frac{\text { The total of the students' score }}{\text { The Total number of students }} \\ & =\frac{2168}{32} \\ & =67.75\end{aligned}$

\section{Siklus 1}

Siklus 1 dilakukan setelah pertemuan pertama sampai akhir pertemuan ketiga penelitian. Untuk memberikan penjelasan detail, saya membagi siklus menjadi empat urutan waktu: setelah pertemuan 1 dan 2 sebelum bertemu, pertemuan 2, setelah bertemu 2 dan sebelum bertemu 3, dan pertemuan 3 .

Saya menyimpulkan bahwa siswa "keterampilan menulis dalam siklus 1 meningkat. Namun, siswa perlu perawatan lebih untuk membuat mereka meningkatkan keterampilan mereka dalam menulis teks recount lebih. 


\section{Siklus 2}

Siklus 2 dilakukan setelah pertemuan ketiga sampai akhir pertemuan kelima penelitian. Untuk memberikan penjelasan detail, saya membagi siklus ini menjadi empat urutan waktu: setelah pertemuan 3 dan 4 sebelum bertemu, pertemuan 4 , setelah bertemu 4 dan 5 sebelum bertemu, dan pertemuan 5. Saya merevisi rencana pelajaran saya ke yang lebih baik untuk mendapatkan lebih banyak perbaikan pada siklus 2 .

Hasil tes formatif menunjukkan bahwa siswa masih mengalami kesulitan dalam semua aspek menulis. Masalah mereka masih sama dengan yang di tes sebelumnya. Namun, jumlah siswa yang melakukan kesalahan baik jumlah kesalahan sendiri menurun dari pre-test.

\section{Hasil Post Test}

Dalam menganalisis hasil post-test, saya membuka grup Facebook "StoryBox" dan membaca siswa "menulis dengan hatihati. Akhirnya, seperti apa yang saya lakukan untuk pre-test dan hasil tes formatif, saya mencetak siswa "hasil posttest satu per satu menggunakan skala analitik Brown dan Bailey untuk tugastugas komposisi rating.

Dari perhitungan saya menemukan bahwa skor terendah dari siswa dalam posttest adalah 75 ; meningkat 8 poin dari tes formatif.Ada 4 siswa yang mendapat 75.Rata tertinggi adalah 89; meningkat 6 poin dari skor tertinggi dalam tes formatif.Hanya satu siswa yang mendapat tanda ini.

\section{Mahasiswa "Respon positif terhadap} Media

Indikator ketiga adalah siswa "respon positif terhadap media.Dalam pre-test, media penulisan adalah kertas.Para siswa merespon negatif kepada media.Mereka tampak bosan ketika mereka diminta untuk melakukan pre-test pada selembar kertas.Hanya 5 siswa yang tertarik untuk menulis. Sisanya tidak tertarik untuk menulis sama sekali.

Ada tidak menyenangkan secara tertulis di atas kertas.Siswa perlu media yang lebih menarik dan menarik untuk meningkatkan motivasi mereka untuk menulis.

Setelah bosan dengan tugas-tugas penulisan, siswa benar-benar penasaran dan tertarik ketika mereka diperkenalkan dengan penggunaan Facebook sebagai media menulis.Dalam siklus 1, jumlah siswa yang menjawab Media meningkat secara positif.Ada 15 siswa yang menunjukkan wajah bahagia saat menulis untuk tes formatif.Hal ini menunjukkan bahwa siswa "tertarik media tulisan baru.

\section{SIMPULAN}

Penelitian ini meneliti menggunakan Facebook sebagai media untuk meningkatkan keterampilan siswa dan meningkatkan motivasi mereka dalam menulis teks recount. yaitu:

(1) Penggunaan Facebook sebagai media pembelajaran meningkatkan kemampuan menulis siswa semester I STAIN Palangakaraya pada tahun akademik 2013/2014. Peningkatan keterampilan siswa dalam menulis dapat dilihat dari nilai ratarata pre-test yang 67,75; tes formatif yang 74,5 , dan post-test yang 79,25. Cara media Facebook meningkatkan keterampilan siswa menulis dapat disimpulkan dari hasil instrumen non-tes. Berdasarkan hasil kuesioner dan lembar obseravation, sebagian besar siswa merasa bahwa kemampuan menulis mereka membaik setelah belajar menulis teks recount dengan Facebook karena (1) mereka menyukai penggunaan Facebook dalam pembelajaran 
mereka, (2) cara Facebook Palangkaraya pada tahun akademik mempresentasikan materi pembelajaran 2013/2014.Peningkatan motivasi siswa membantu mereka dalam mengakui hal itu, dapat dilihat dari hasil instrumen non-tes. (3) berbagi penghitungan ulang teks di Analisis non-test menunjukkan bahwa Facebook membuat mereka lebih imajinatif setelah mempelajari teks menulis recount dan kreatif dalam menulis, (4) Facebook menggunakan Facebook, para siswa membantu mereka mengatasi kesulitan menjadi lebih perhatian, aktif, dan menarik dalam menulis teks recount seperti: bergabung pelajaran; dan lebih bahagia dan menemukan ide-ide, penggunaan struktur lebih serius dalam menulis. Penggunaan tata bahasa yang benar dan, menemukan Facebook meningkatkan motivasi mereka kosakata baru, dan tentang menulis gaya, untuk menulis karena(1) mereka suka (5) mereka menjadi lebih teliti saat menulis cerita karena akan dibaca oleh banyak teman dan guru, (6) review dari pengajar dan teman-teman membantu mereka menyadari kesalahan mereka sehingga mereka tidak akan mengulangi lagi nanti, dan (7) kemampuan menulis mereka ditingkatkan dengan mengomentari teman mereka dalam menulis di Facebook.

(2) Penggunaan Facebook sebagai media pembelajaran dapat meningkatkan motivasi menulis siswa semester I STAIN menulis di Facebook, itu lebih bebas dan lebih menyenangkan, (2) menulis bahasa Inggris di Facebook yang menantang, (3) mereka merasa lebih antusias dalam menulis karena komentar dan kesukaan pada tulisan mereka, (4) mereka menyukai berbagi cerita dengan banyak orang di Facebook, (5) mereka suka mengomentari tulisan satu sama lain dan (6) mereka merasa termotivasi untuk menulis lebih baik karena tulisan mereka akan dibaca oleh banyak orang, tidak hanya oleh pengajar.

\section{DAFTAR PUSTAKA}

Anderson, M. and Anderson, K. 1997. Text Type in English 1. South Melbourne: Macmillan.

Bartlett-Bragg, A. 2006. Reflections on Pedagogy: Reframing Practice to Foster Informal Learning with Social Software. Australia. Online.Available at http://matchsz.inf.elte.hu/tt/docs/Anne20Bartlett-Bragg.pdf [accessed03/18/13]

Brown, H. D. 2004. Language Assessment: Principles and Classroom Practices. New York: Pearson Education.

Byrne, Donn.1980. Teaching Writing Skill. London; Longman Group Ltd

Blanchard, K. L \& Root, C. B. 1984.Ready to Write: First Composition Text. New York: Longman

Brown, H. D. 2004. Language Assessments, Principles and Classroom Practices. New York: Longman.

Boyd, D.M, Ellison, N.B. 2007. Social Network Sites: Definition, History, and Scholarship. Michigan State Unversity. Online.Available athttp://mimosa.pntic.mec.es/mvera1/textos/redessociales.pdf [accessed 03/18/13]

Colton, D. \& Covert, R. W. 2007.Designing and Constructing Instruments for Social Research and Evaluation.Jossey-Bass [e-book]. Available at http://ifile.it/h2co6km/0787987840.zip [september 2011] 
Pedagogik Jurnal Pendidikan, Maret 2015, Volume 10 Nomor 1, (51-61)

Derewianka, B. 2004.Exploring How Text Work. Sydney: Primary English Teaching Association.

Eren, O. 2012. Students $\square$ Attitudes towards Using Social Networking in Foreign Language Classes: A Facebook Example. International Journal of Business and Social Science Vol. 3 No. 20.

Harmer, J. 2001.The Practice of English Language Teaching. London: Longman. . 2004. How to Teach Writing. Essex: Pearson Education Limited.

Harmer, J. B. 2004.How To Teach Writing.London: Longman

Merchant, Guy. 2013. Unravelling the Social Network: Theory and Research. Learning, Media and Technology Vol. 37, No. 1, March 2012, Pp 4-19. London: Routledge. Available http://www.tandfonline.com/doi/pdf/10.1080/17439884.2011.567992 [accessed 05/31/13]

Ormrod, J.E. 2010. How Motivation Affects Learning and Behavior. Online. Available at http://www.education.com/reference/article/motivation-affects-learningbehavior/ [accessed 09/02/13] 